\title{
アセスメントと評価
}

沖縄県立看護大学学長 ·保健看護学研究科教授

\section{上田 礼子}

アセスメントや評価という用語は一般にも頻繁 に用いられている。アセスメントは，専門分野に よって, 環境アセスメント, 発達的アセスメント, フィジカルアセスメント, ヘルスアセスメント， 通文化アセスメント (cross-cultural assessment), 文化的アセスメント, QOL アセスメント・インス トルメント (WHOQOL) などの用語として使用さ れている．英和辞典によれば，アセスメントとい う用語はもともと「課税のための查定」という意 味で用いられていた。 それが身体機能，あるいは 健康状態の査定, 文化的查定などのように現状把 握のために用いられている.

発達的アセスメントの場合には(1)診断名のつく 病気の有無, また, (2)生命の誕生から年月齢に伴っ て出現 (消失) する個人の能力の測定に用いられ る.“誰が”,“何の目的で”, “誰を”, “どのような方 法で”, “何時”, “どこで”測定するかによって種々 の測定尺度が考案されて実用化されてきた。 これ らは種々の発達検査や発達スクリーニング検査, 知能検查として知られている. (1)に用いられる測 定尺度の概念は疾病的基準であり，(2)の概念は統 計的基準である.

一方, 「評価」とは人間の持つ豊富な適応能力と 個人と環境との相互作用によって発現あるいは消 失する行動に焦点をあてて, 価值概念に従って“良 し”または“良くない”と判断することである. すなわち，個人の属する文化・社会の価值的基準 に立った判断である。このようにアセスメントと 評価とは全く同じ概念ではなく，評価には価值観 が含まれる点で大きく違っている．特定のアセス メントの尺度は，誰かがどこかで何らかの目的で 何らかの手続きで作成したものである，そのアセ スメント尺度を違う文化・社会的背景にあるもの に適用した場合には，その意味と結果の評価を問
わなければならない. 生物学的モデルを超えた文 化的アセスメントモデルが求められているのであ る.

グローバル化に伴って世界中の情報は瞬時に入 手できるようになった。 また，物や人も交流し急 速に変化している．しかしその一方，これらの変 化に取り残されている国や地域もあり，人々の価 值観は多様化している.これらの状況をふまえて 人間の発達や健康のアセスメントのパラダイム シフトが 1990 年代から欧米を中心に提唱されて いる．具体的には白人・中産階級の人々を対象と して開発されたアセスメント・ッールは，少数集 団の白人以外の者, 他の社会階層の者にどれだけ 妥当性・信頼性があるかという問題提起である. 筆者はすでに 1970 年代に, 日本人とは人種や養育 環境・文化の異なる米国デンバー市で標準化され た発達スクリーニング検查を, 文化・社会の異な る日本の乳幼児に適用すると偽陽性の出現率が高 いことをみいだし，日本の子ども 2510 名を対象に 標準化し，日本の中の地域差に応じて新たに補正 版を作成した経験がある，人間の発達 (う健康)は 身体面だけではなくこよなく心理・社会的側面を 含むホーリスティックアプローチを必要としてい る. 身体的アセスメントモデルから身体的心理的 社会的な個人 (健康) と環境が相互作用する適応 行動をアセスメントし，評価する方向へのパラダ イム・シフトが不可避である，人々の日常生活行 動を方向付けている文化的意味システム (cultural meaning systems）を無視して他国で開発された アセスメント・ッールと評価法を国内で用いるこ とは(学問的演習としてはよいかもしれないが)我 が国の人々に害際はあまり役立たない。無駄な仕 事になる。

日本の家屋一畳の家に住むには靴よりも下駄や 
草履が簡単に脱いだりはいたりできるので便利で ある. しかし，洋風化に伴って靴を履くことが日 本人にも多くなったものの自分の足のサイズに ぴったり合う既製の靴をみつけるのは必ずしも容 易ではない，逆に靴に足を合わせる努力をするこ とも時には生じることがあろう.

類似のことは他の国や違う文化圈内で作成され たアセスメント・ツールや評価方法を翻訳して文 化の異なる我が国に用いることにも当てはまる.
特に社会・心理的機能のアセスメントや評価，イ ンターベンションなどは文化的要因が重要な因子 である，真に我が国の人々に貢献できるアセスメ ント・評価の開発が望まれる。それは実は日本一 国だけに役立つものではなく, 人間の生活行動の 普遍性を探求することに役立ち, 他国や他文化圈 の人々にも役立ち, 相互理解を深める契機となる のである. 